\title{
An Inbred Line of Transgenic Mice Expressing an Internally Deleted Gene for Type II Procollagen (COL2A1) \\ Young Mice Have a Variable Phenotype of a Chondrodysplasia and Older Mice Have Osteoarthritic Changes in Joints
}

\author{
Heikki J. Helminen, * Kari Kiraly, ${ }^{*}$ Alpo Pelttari, ${ }^{3}$ Markku I. Tammi," Philipp Vandenberg, * Ruth Pereira, * Rohini Dhulipala, * \\ Jaspal S. Khillan, * Leena Ala-Kokko, * Eric L. Hume, ' Boris P. Sokolov, * and Darwin J. Prockop* \\ * Department of Biochemistry and Molecular Biology, Jefferson Institute of Molecular Medicine, and 'Department of Orthopaedic \\ Surgery, Jefferson Medical College, Thomas Jefferson University, Philadelphia, Pennsylvania 19107; and ${ }^{\ddagger}$ Department of Anatomy \\ and ${ }^{\S}$ Laboratory of Electron Microscopy, University of Kuopio, SF-70211 Kuopio, Finland
}

\begin{abstract}
Studies were carried out on a line of transgenic mice that expressed an internally deleted COL2A1 gene and developed a phenotype resembling human chondrodysplasias (Vandenberg et al. 1991. Proc. Natl. Acad. Sci. USA. 88:7640-7644. Marked differences in phenotype were observed with propagation of the mutated gene in an inbred strain of mice in that $\sim 15 \%$ of the transgenic mice had a cleft palate and a lethal phenotype, whereas the remaining mice were difficult to distinguish from normal littermates. 1-d- and 3-mo-old transgenic mice that were viable showed microscopic signs of chondrodysplasia with reduced amounts of collagen fibrils in the cartilage matrix, dilatation of the rough surfaced endoplasmic reticulum in the chondrocytes, and decrease of optical path difference in polarized light microscopy. The transgenic mice also showed signs of disturbed growth as evidenced by lower body weight, lower length and weight of the femur, decreased bone collagen, decreased bone mineral, and decreased resistance of bone to breakage. Comparisons of mice ranging in age from $1 \mathrm{~d}$ to 15 mo demonstrated that there was decreasing evidence of a chondrodysplasia as the mice grew older. Instead, the most striking feature in the 15-mo-old mice were degenerative changes of articular cartilage similar to osteoarthritis. (J. Clin. Invest. 1993. 92:582-595.) Key words: animal models • chondrodysplasias • mutations of type II procollagen gene • osteoarthritis • type II collagen
\end{abstract}

\section{Introduction}

Type II collagen is the most abundant macromolecule of cartilage matrix $(1,2)$. Therefore, it is an important component of the cartilage matrix that is formed during early development of

A preliminary abstract on the whole report was presented at the Fourth International Conference on Molecular Biology and Pathology of Matrix, Jefferson Medical College, 10-13 June 1992 (Helminen et al. 1993. Matrix. Abstract in press).

Address reprint requests to Dr. Darwin J. Prockop, Department of Biochemistry and Molecular Biology, Jefferson Institute of Molecular Medicine, Jefferson Medical College, 233 South Tenth Street, Room 350 BLSB, Philadelphia, PA 19107.

Received for publication 27 October 1992 and in revised form 10 March 1993.

J. Clin. Invest.

(c) The American Society for Clinical Investigation, Inc.

$0021-9738 / 93 / 08 / 0582 / 14 \$ 2.00$

Volume 92, August 1993, 582-595 most skeletal structures, and it plays a critical role in bone formation through endochondral ossification. In addition, recent reports indicate that transient tracks of type II collagen fibrils appear at epitheliomesenchymal interfaces during the early development of the craniofacial system, the heart, the brain, and other organs (3-5). In adult animals, type II collagen is a major source of the structural strength and resilience of hyaline cartilage in tissues such as the articular surfaces of joints and the nucleus pulposus of the intervertebral discs. Over the past several years, mutations in the gene for type II collagen (COL2A1) were shown to cause several chondrodysplasias, a heterogenous group of over 150 heritable disorders that are characterized by malformations of cartilaginous structures, and degenerative changes of joints (see reference 6). Alleles of the COL2A1 gene were linked to arthro-ophthalmopathy or the Wagner-Stickler syndrome in about half of a series of families examined (7-9), and four mutations introducing premature termination codons into the COL2A 1 gene were identified as a cause of the disease (10-13). Mutations in the COL2A1 gene were also identified in a proband initially described as having a form of achondrogenesis and subsequently described as a lethal perinatal form of short-limbed dwarfism (14) and in four probands with spondyloepiphyseal dysplasia (15-17; Williams, manuscript in preparation). In addition, alleles of the COL2A1 gene were shown to be linked to primary generalized osteoarthritis in two families (18), and a mutation in the COL2A1 gene was found to cause primary generalized osteoarthritis associated with a mild chondrodysplasia in another family (19).

The effects of mutations in the COL2A1 gene are usually interpreted with reference to the more extensive information now available about the effects of mutations in the two genes for type I procollagen (COL1A1 and COL1A2). Over $100 \mathrm{mu}-$ tations in the genes for type I procollagen have been defined as a cause of osteogenesis imperfecta $(20,21)$. Most of the mutations in severely affected probands cause synthesis of abnormal but partially functional pro $\alpha$ chains of the protein. The causal relationships between mutations in genes for type I procollagen and the disease phenotypes were established through linkage studies in families with milder forms of the disease, and extensive data on the effects of the mutations on the synthesis of type I procollagen by cultured skin fibroblasts, on the thermal stability of the collagen triple helix, and on the self-assembly of the collagen into fibrils (20-22). In addition, the causal relationships between the mutations and the disease phenotypes was demonstrated directly by observations indicating that expression of mutated COL1A1 genes in transgenic mice produced phenotypes similar to human osteogenesis imperfecta (23-25). 
The biosynthetic pathway and structure-function properties of type II procollagen are very similar to those for type I procollagen $(22,26)$. Therefore, because the mutations in the type II procollagen gene found in probands with chondrodysplasias are similar to the mutations found in the type I genes in patients with osteogenesis imperfecta, it has been reasonable to assume that the COL2A1 mutations are a cause of the disease phenotypes. Linkage studies, however, have been performed in only a few families with mild chondrodysplasias (7-9). In addition, cartilage is only rarely available from probands and human cartilage cells do not grow well in culture. Therefore, defining the causal relationship between the gene mutations and the disease phenotypes has been difficult. Recently, we prepared transgenic mice expressing an internally deleted version of the human COL2A1 gene and demonstrated that mice expressing the internally deleted gene developed a phenotype similar to some human chondrodysplasias with dwarfism, a short snout, a cranial bulge, a cleft palate, and delayed mineralization of bone (27). Also, Garofalo et al. (28) and Metsäranta et al. (29) reported that similar phenotypes of severe chondrodysplasias were produced in transgenic mice that expressed COL2A1 genes mutated either with a substitution of a cysteine codon for glycine at amino acid position $\alpha 1-85$ in the $\alpha 1$ (II) chain or with a deletion of $150 \mathrm{bp}$ that eliminated the 15 codons of exon 7 and, therefore, amino acids 4-18 of the $\alpha 1$ (II) chain. In addition, Nakata et al. (30) reported that expression of a truncated gene for the $\alpha$ (IX) chain of type IX collagen in transgenic mice produced articular cartilage disorders.

Here we have examined a line of transgenic mice that expresses an internally deleted COL2A 1 gene and that develops a phenotype resembling human chondrodysplasias (27). The results demonstrate that the phenotype is highly variable in its severity even when the mutation is propagated in an inbred strain of mice. In addition, the results demonstrate that after 12 or $15 \mathrm{mo}$, the transgenic mice with the mildest phenotype develop degenerative changes in joints resembling osteoarthritis.

\section{Methods}

Transgenic mice. Transgenic mice were generated using the human type II procollagen construct described by Vandenberg et al. (27). The construct was prepared by cleaving a cosmid clone of the human COL2A1 gene (31; provided by Dr. Francesco Ramirez, Mt. Sinai School of Medicine, New York) with XbaI, SphI, and ClaI to generate four fragments of the gene and then reassembling the gene in a cosmid vector without an internal 5-kb ClaI/SphI fragment. The initial cosmid clone of the gene extended from $\sim-2 \mathrm{~kb}$ of the promoter region to $\sim 80$ bp beyond the major polyadenylation signal. Removal of the 5-kb ClaI/SphI fragment deleted a region that extended from intron 15 to intron 27 and contained 12 of the 54 exons of the gene. The internally deleted gene construct, therefore, coded for a shortened pro $\alpha 1$ (II) chain with an in-frame deletion of 291 amino acids ( $\alpha 1-157$ to 447) of the 1,014-residue-long triple-helical domain. The transgenic mice were generated and propagated in the inbred FVB/N strain (Fig. 1).

For detection of transgenic mice, one toe of the newborn mice was cut and the tissue was incubated at $55^{\circ} \mathrm{C}$ for $1 \mathrm{~h}$ in $0.1 \mathrm{ml}$ of $10 \mathrm{mM}$ Tris- $\mathrm{HCl}$ buffer containing $50 \mathrm{mM} \mathrm{KCl}, 5 \mathrm{mM} \mathrm{MgCl}, 0.5 \mathrm{mg} / \mathrm{ml}$ gelatin (Sigma Chemical Co., St. Louis, MO), 1\% Brij-35, and 0.4 $\mathrm{mg} / \mathrm{ml}$ proteinase $\mathrm{K}$ (Boehringer-Mannheim Biochemicals, Indianapolis, IN). A region of the human COL2A1 gene was amplified with a specific PCR protocol (D. Bertolette, M. Arita, and J. S. Khillan, unpublished data). The oligonucleotide primers were EIF (5'-TTGGGTGTGATCTGAAGCATC-3') and EIR ( 5'-AGCCAGCTAAGTCTGTCTGTA- $3^{\prime}$ ) that hybridize to introns 13 and 14 , respectively, of the

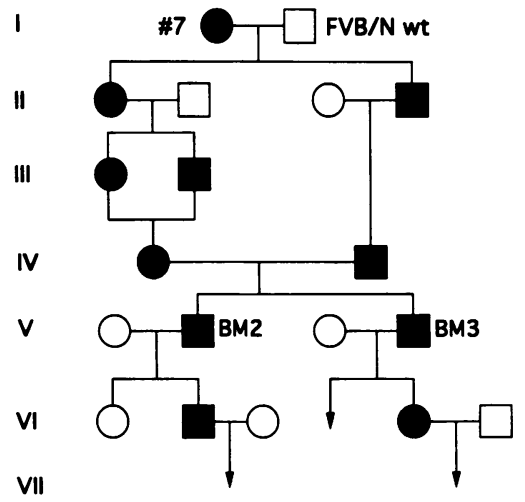

Figure 1. Breeding of line 7. All mice were from the inbred FVB/N strain. Only selected progeny from the matings are shown. The matings in generations III and IV were carried out to generate viable homozygotes but none were obtained (see text). Most experiments here were carried out on the heterozygous progeny of the mice

designated as BM2 and BM3. Symbols: $(\bullet, \bullet)$ heterozygous transgenic mice; $(O, \square)$ wild-type FVB/N mice.

gene. A 546-bp fragment was amplified. The thermal cycling reaction conditions were $94^{\circ} \mathrm{C} / 56^{\circ} \mathrm{C} / 72^{\circ} \mathrm{C}$ for $1.5 \mathrm{~min} / 1.0 \mathrm{~min} / 1.0 \mathrm{~min}$ for 30 cycles. The products were electrophoresed in a $2.5 \%$ agarose gel.

For assay of gene copy number, a terminal piece of tail was minced in $0.7 \mathrm{ml}$ of $100 \mathrm{mM} \mathrm{NaCl} / 100 \mathrm{mM}$ EDTA/1\% SDS in $50 \mathrm{mM}$ Tris$\mathrm{HCl}$ buffer ( $\mathrm{pH} 8.0$ ) and digested overnight at $55^{\circ} \mathrm{C}$ with $0.5 \mu \mathrm{g} / \mathrm{ml}$ of proteinase $\mathrm{K}$. The digested sample was extracted with phenol/chloroform/isoamyl alcohol (25:24:1) and then extracted with chloroform/ isoamyl alcohol (24:1). The DNA was precipitated with ethanol and dissolved in $1 \mathrm{mM}$ EDTA in $10 \mathrm{mM}$ Tris- $\mathrm{HCl}$ buffer ( $\mathrm{pH} \mathrm{7.4)}$. To assay gene copy number, the transgene and the endogenous COL2A 1 gene was simultaneously amplified with the same set of primers that generated fragments of two different sizes from the two genes. One primer hybridized to exon 50 and had the sequence 5'-GCTGCACCTTGGACGCCATGA. The second primer hybridized to exon 51 and had the sequence 5'-CAGTGGTAGGTGATGTTCTGGGA. The DNA was amplified by PCR (GeneAmp PCR reagent kit; PerkinElmer Cetus, Norwalk, CT) with primer concentrations of $50 \mathrm{pmol}$ in a $100-\mu l$ reaction mixture. Amplification conditions were 28 cycles with $1.5 \mathrm{~min}$ at $94^{\circ} \mathrm{C}$ and $1.5 \mathrm{~min}$ at $65^{\circ} \mathrm{C}$. One of the primers used in PCR was $5^{\prime}$-labeled with ${ }^{32} \mathrm{P}$ using a $5^{\prime}$ DNA terminus labeling system (GIBCO-BRL, Grand Island, NY). $3 \mu$ of the product was separated by 5\% PAGE. The gel was fixed, dried, exposed to $x$-ray film, and assayed with a laser scanner (Pharmacia, Inc., Piscataway, NJ). The human COL2A1 transgene generated a fragment of $603 \mathrm{bp}$ and the endogenous mouse gene generated a fragment of $557 \mathrm{bp}$.

Bone weight, length, diameter, and area measurements. Femoral bones were dissected free and cleaned from surrounding tissues in phos-

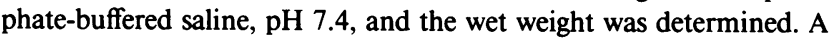
stereomicroscope (model M3Z, Wild Heerbrugg, Switzerland) equipped with a drawing mirror was used to draw the outlines of the intact bones, of the upper and lower surface areas of the bone cylinder after sawing (Isomet Low Speed Saw, Buehler Ltd., Lake Bluff, IL), of the epiphyseal bone stub from the femur, and of the inner and outer diameter of the diaphysis after the biomechanical tests. The lengths, diameters, and areas of the bones were determined from the drawings by aid of an interactive digital analysis system (ZIDAS, Carl Zeiss, Inc., Thornwood, NY).

Light and electron microscopy. Tissues of anesthetized newborn and adult mice were fixed by perfusion through the heart with $2 \%$ paraformaldehyde and $2.5 \%$ glutaraldehyde buffered to $\mathrm{pH} 7.3$ with 0.1 $M$ phosphate buffer. After 10-15 min of perfusion, nasal cartilage and knee joints were immersed overnight in the same fixative at $4^{\circ} \mathrm{C}$. Decalcification was carried out by immersing the tissues in 10\% EDTA and $0.5 \%$ paraformaldehyde buffered with $0.1 \mathrm{M}$ phosphate buffer $(\mathrm{pH}$ 7.4). The solution was changed every other day for $14 \mathrm{~d}$. Samples for electron microscopy were postfixed with $1 \%$ osmium tetroxide in $0.1 \mathrm{M}$ cacodylate buffer $\left(\mathrm{pH} \mathrm{7.4)}\right.$ for $2 \mathrm{~h}$ at $20^{\circ} \mathrm{C}$, washed three times with the cacodylate buffer, and then placed in $1 \%$ tannic acid in $0.1 \mathrm{M}$ cacodyl- 


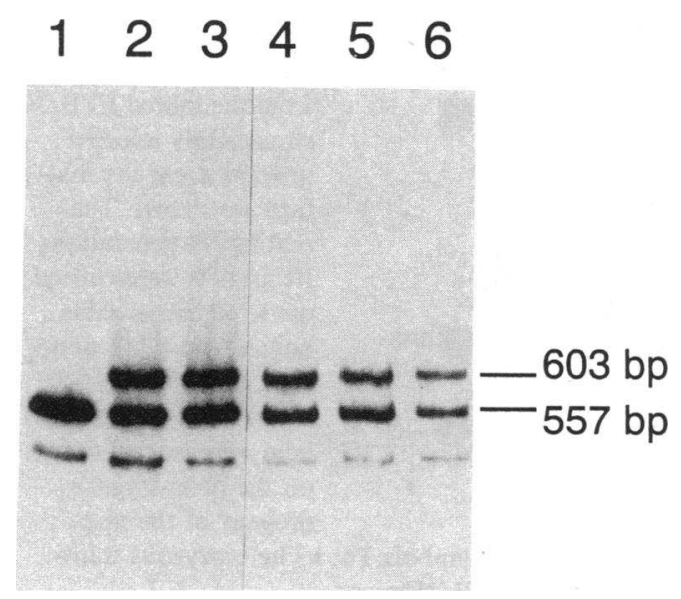

Figure 2. Assay of gene copy number in heterozygous transgenic mice. As described in Methods, the same primers were used to amplify a sequence of $603 \mathrm{bp}$ from the COL2A1 transgene and a sequence of $557 \mathrm{bp}$ from the endogenous mouse COL2A1 gene. Lane 1: Control littermate. Lanes 2-6: Heterozygous mice from line 7 generation II, IV, V, VI, and VII (See Fig. 1).

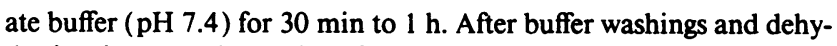
dration in ascending series of ethanol solutions, the specimens were embedded in epon. Sections 50-60-nm thick were cut, and stained with uranyl acetate for $30 \mathrm{~min}$, followed by staining with lead citrate for 2-4 min. They were examined with JEM 1200 EX electron microscope (JEOL, Tokyo, Japan).

For polarized light microscopy, $5 \mu$-thick sections were cut from paraffin-embedded specimens, extracted with xylol at $37^{\circ} \mathrm{C}$ overnight, and digested with $2 \mathrm{mg} / \mathrm{ml}$ of hyaluronidase (Sigma Chemical Co.) at $37^{\circ} \mathrm{C}$ overnight. The specimens were then stained with sirius red (picrosirius staining). The sections were analyzed with an Ortholux 2 Pol-BK microscope (E. Leitz, Wetzlar, FRG) operated in monochromatic light $(\lambda=591 \mathrm{~nm}$ filter for cartilage and $\lambda=656 \mathrm{~nm}$ filter for bone; Schott, Mainz, FRG) using the de Sénarmont compensation technique.

Microscopic evaluation of osteoarthritic changes. For evaluation of osteoarthritic changes in the mouse knee joint, the grading proposed by Wilhelmi and Faust (32) was used. The scores were the following: 0 = no apparent changes; 1 = superficial fibrillation, striation of cartilage (or cystic change); 2 = injuries limited to uncalcified cartilage; 3 $=$ defects extending into calcified cartilage; $4=$ deep defects extending into the subchondral and/or trabecular bone. The left knee joint of mouse was serially sectioned in frontal plane and the sections were investigated after staining with both picrosirius and safranin $O$. The knee joint was divided into two compartments. The medial condyles of femur and tibia formed the medial compartment. The lateral compartment was made up by the lateral femoral and tibial condyles.

$X$-ray analysis, skeletal staining, and spontaneous movements. $\mathrm{X}$ ray analysis of the skeleton was performed with a cabinet $\mathrm{X}$-ray system (Cabinet; Hewlett-Packard Co., McMinnville, OR). For further analysis of skeletons, specimens were differentially stained with alcian blue for cartilage and alizarin red $\mathrm{S}$ for bone followed by alkali digestion (33). Spontaneous movements of the mice in their own cages at the 3and 15-mo intervals were recorded on two consecutive days by a small animal movement monitor (model 152-01, Coulibourn Instruments, Lehigh Valley, PA).

Assay of collagen and bone mineral. Bone tissue was homogenized with mechanical grinder (Tissuemizer, Tekmar Co., Cincinnati, $\mathrm{OH}$ ) followed by further homogenization with a motor-driven sintered glass homogenizer. The homogenate was first dialyzed for $4 \mathrm{~d}$ against $0.5 \mathrm{M}$ EDTA ( $\mathrm{pH} \mathrm{8.0)} \mathrm{followed} \mathrm{by} \mathrm{dialysis} \mathrm{against} \mathrm{distilled} \mathrm{water} \mathrm{for} 1 \mathrm{~d}$. A sample of the homogenate was hydrolyzed in $6 \mathrm{~N} \mathrm{HCl}$ at $100^{\circ} \mathrm{C}$ overnight and the collagen hydroxyproline was assayed by the method of Woessner (34). To determine the mineral (ash) weight, the bones were wrapped in aluminum foil, ashed in oven at $600^{\circ} \mathrm{C}$ (Thermolyne type 1400 furnace, Barnstead/Thermolyne, Dubuque, IA) for 18-24 h and weighed. Collagen and mineral assays were separately performed on the diaphyseal and epiphyseal parts of the femur. The epiphyseal bone parts contained most, if not all, of the growth cartilage.

Biomechanical testing. For biomechanical testing of the diaphysis, the three-point bending test was performed with an instrument designed for this purpose (Universal Testing Machine; Instron Corp., Canton, MA) as described by Kiebzak et al. (35). The ends of the diaphysis were supported by two fulcra separated by a distance of 5 $\mathrm{mm}$. Force was applied at the midshaft and perpendicular to the long axis of the diaphysis by a blunt indenter edge moving at a constant speed of $10 \mathrm{~mm} / \mathrm{min}$. A force-deformation curve was obtained from a recorder, and the load to bone failure, stiffness, and total energy needed to break the bone was measured from the graph. The load to bone failure ( $\mathrm{Nt}$ ) was assayed as the peak of the curve. Deformation at the break point was estimated from the curve by measuring the distance between the start point of loading and the bone break on the abscissa. The stiffness $(\mathrm{Nt} / \mathrm{m})$ of the bone was determined from the slope of the force-deformation curve. The area underneath the curve was taken as the energy $(\mathrm{Ntm})$ needed to break the bone.

\section{Results}

The line of transgenic mice. Several lines of transgenic mice were prepared that expressed an internally deleted construct of the human COL2Al gene (27). The construct was designed so

Table I. Transgenic Mice of Line 7

\begin{tabular}{|c|c|c|c|c|c|c|c|}
\hline \multicolumn{2}{|c|}{ Mating pair* } & \multicolumn{3}{|c|}{ Offspring $^{t}$} & \multicolumn{3}{|c|}{ Phenotype of transgenics } \\
\hline Male & Female & Litters & $\begin{array}{l}\text { Total } \\
\text { mice }\end{array}$ & Transgenics & $\begin{array}{c}\text { Cleft } \\
\text { palate }\end{array}$ & $\begin{array}{c}\text { Dead at } \\
\text { birth }^{8}\end{array}$ & Viable \\
\hline & & & & & & & \\
\hline Transgenic & FVB/N wt & 55 & 458 & $220(48 \%)$ & $34(15 \%)$ & 21 & $186(85 \%)$ \\
\hline FVB/N wt & Transgenic & 19 & 128 & $63(49 \%)$ & $9(14 \%)$ & 11 & $52(83 \%)$ \\
\hline Transgenic & Transgenic & 11 & 85 & $61(72 \%)$ & $23(38 \%)$ & 17 & $38(62 \%)$ \\
\hline
\end{tabular}

* Transgenic animals were from the founder of line 7 (see Fig. 1) and they were generated by transgenic $\times$ FVB/N wild-type breeding and transgenic $\times$ transgenic matings. ${ }^{\ddagger}$ From transgenic $\times$ FVB/N wild-type matings the male/female ratio in 169 transgenic mice at 3 wk was 0.86 vs. 0.98 in 190 normal littermates. From transgenic $\times$ transgenic matings the male/female ratio at 3 wk was 0.59 in 35 transgenic mice vs. 0.75 in 14 normal littermates. 3 Most transgenic mice with a cleft palate were dead a few hours after birth, but several survived for $1 \mathrm{~d}$. 19 of 303 normal littermates were also dead within a few hours of birth. 

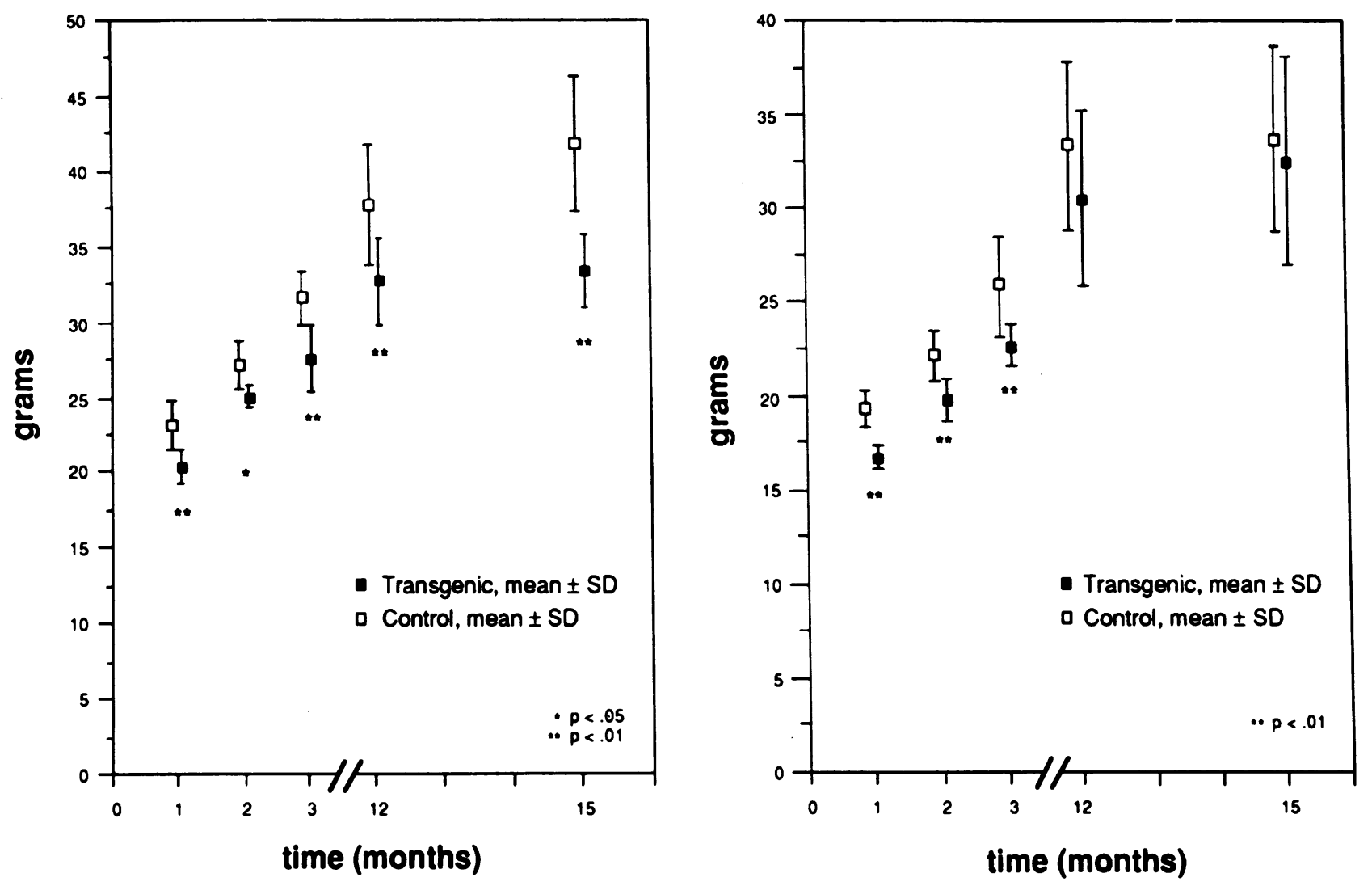

Figure 3. The growth curves of the control and transgenic (left) male and (right) female mice.

as to cause synthesis of shortened proal(II) chains that would associate with and become disulfide-linked to normal pro $\alpha 1$ (II) chains synthesized from the endogenous mouse COL2Al gene. As a result, expression of the gene would cause depletion of the mouse type II procollagen because fibrillar procollagens containing both markedly shortened and fulllength pro $\alpha 1$ (II) chains cannot fold into a stable triple helix and are degraded $(21,22,26)$. The phenotypes of the transgenic mice from different lines varied from normal to a lethal chondrodysplasia characterized by dwarfism, delayed mineralization, and cleft palate (27).

The line selected for study here was originally designated as line 7 (27). To develop a breeding stock, the $F_{0}$ female founder of line 7 in the FVB/N inbred strain was mated with a wildtype FVB/N male and the line was propagated in the same inbred FBV/N strain (Fig. 1). Also, brother-sister matings were carried out in the third and fourth generations (III and IV in Fig. 1) in an attempt to obtain homozygous mice, i.e., mice

Table II. Weight and Length of Femurs from 3- and 15-mo-old Female Transgenic Mice*

\begin{tabular}{|c|c|c|c|c|c|c|}
\hline & \multicolumn{2}{|c|}{ Wet weight } & \multicolumn{2}{|c|}{ Length } & \multicolumn{2}{|c|}{ Width/length } \\
\hline & 3-mo & 15-mo & 3-mo & 15 -mo & 3-mo & 15-mo \\
\hline & \multicolumn{2}{|c|}{$m g$} & \multicolumn{2}{|c|}{$\mathrm{mm}$} & & \\
\hline \multicolumn{7}{|l|}{ Whole femur } \\
\hline Control & $57.6 \pm 2.4$ & $65.1 \pm 6.2$ & $15.2 \pm 0.6$ & $15.4 \pm 0.3$ & $0.107 \pm 0.004$ & $0.107 \pm 0.004$ \\
\hline Transgenic & $49.6 \pm 1.5^{\prime \prime}$ & $58.9 \pm 5.2^{\S}$ & $13.6 \pm 0.8^{\prime \prime}$ & $14.1 \pm 0.5^{\prime \prime}$ & $0.116 \pm 0.004^{\prime \prime}$ & $0.123 \pm 0.011^{\S}$ \\
\hline \multicolumn{7}{|l|}{ Epiphysis } \\
\hline Control & $21.2 \pm 1.9$ & $22.6 \pm 3.4$ & & & & \\
\hline Transgenic & $19.6 \pm 1.3^{\ddagger}$ & $22.0 \pm 1.8$ & & & & \\
\hline \multicolumn{7}{|l|}{ Diaphysis } \\
\hline Control & $32.6 \pm 3.0$ & $36.9 \pm 3.1$ & & & & \\
\hline Transgenic & $26.5 \pm 3.2^{11}$ & $32.6 \pm 5.3^{\S}$ & & & & \\
\hline
\end{tabular}

* From 13 to 17 mice were used to assay wet weight, length, and mineral of femurs. Values are mean \pm SD. ${ }^{\ddagger} P<0.05$, almost significant; $8 P$ $<0.01$, significant; " $P<0.001$, highly significant difference between the transgenic and control groups (Student's $t$ test and Mann-Whitney's $\mathrm{U}$ test). 

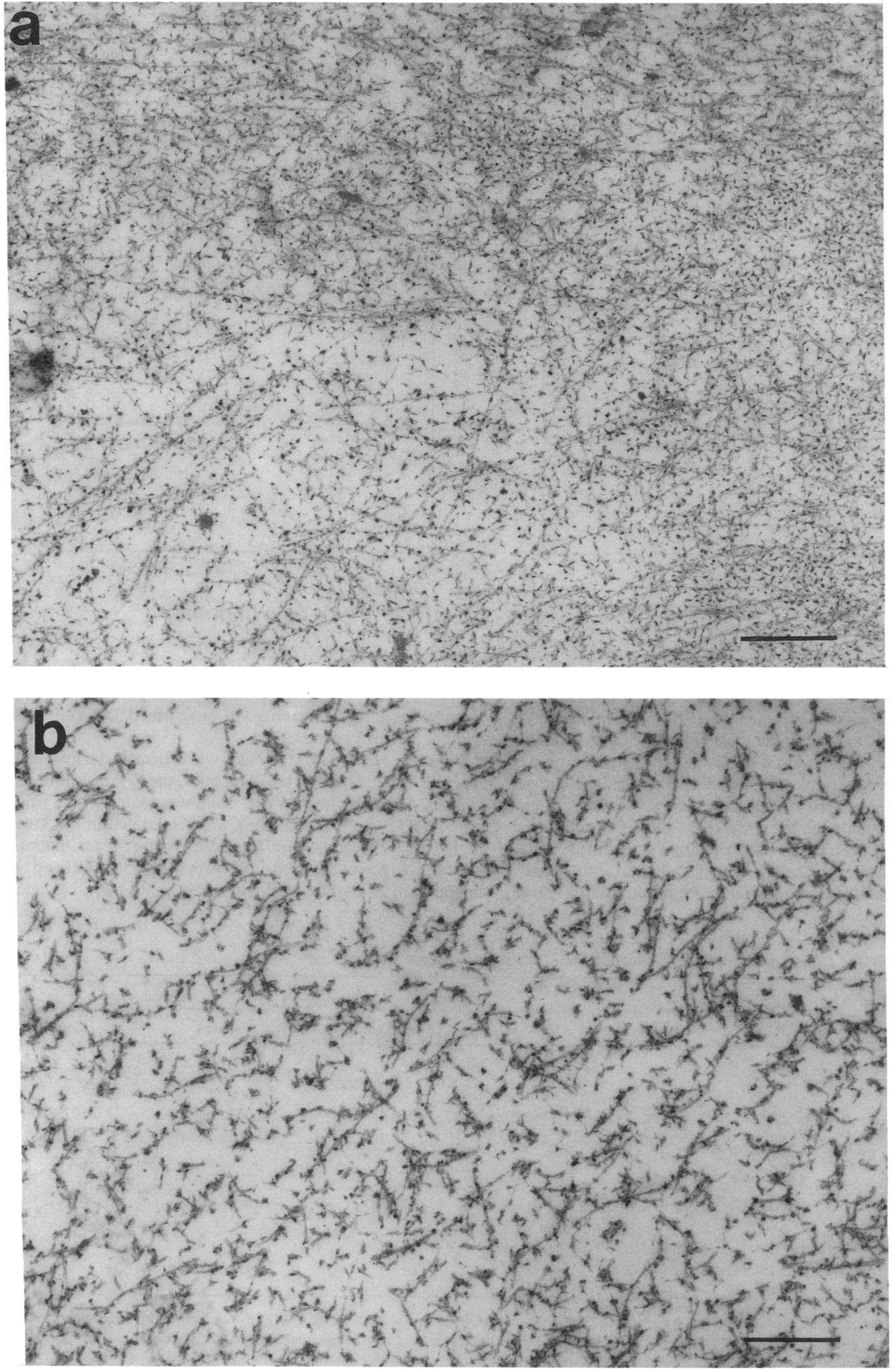
Table III. Electron Microscopy of Cartilage from Male Transgenic Mice*

\begin{tabular}{|c|c|c|c|c|}
\hline \multirow[b]{2}{*}{ Age } & \multirow[b]{2}{*}{$\begin{array}{c}\text { Decrease } \\
\text { in matrix } \\
\text { fibrils }\end{array}$} & \multicolumn{2}{|c|}{ Cells } & \multirow[b]{2}{*}{$\begin{array}{l}\text { Cartilage } \\
\text { surface }\end{array}$} \\
\hline & & $\begin{array}{c}\text { Dilation } \\
\text { of rough } \\
\text { endoplasmic } \\
\text { reticulum }\end{array}$ & $\begin{array}{l}\text { Glycogen } \\
\text { and/or lipid } \\
\text { droplets }\end{array}$ & \\
\hline \multicolumn{5}{|l|}{ 1-d-old } \\
\hline Nasal septum & $+++^{\ddagger}$ & ++++ & ++ & \\
\hline Growth plate & $+++^{\ddagger}$ & $++++^{8}$ & + & \\
\hline Condyles & $+++^{\ddagger}$ & ++ & 0 & Smooth \\
\hline \multicolumn{5}{|l|}{ 3-mo-old } \\
\hline Nasal septum & \pm & ++ & ++11 & \\
\hline Growth plate & \pm & +++ & 0 & \\
\hline Condyles & \pm & ++ & 0 & Smooth \\
\hline \multicolumn{5}{|l|}{15 -mo-old } \\
\hline Nasal septum & \pm & + & $++++l 1$ & \\
\hline Growth plate & \pm & ++ & 0 & \\
\hline Condyles & \pm & 0 & 0 & Eroded \\
\hline
\end{tabular}

* Symbols used: $0=$ little or none present; $\pm=$ no distinct difference; $+=$ slight difference from control; $++=$ difference from control; $+++=$ clear difference from control; $++++=$ very clear difference from control. ${ }^{\ddagger}$ Also, fibrils appeared to be shorter and kinked.

${ }^{8}$ Dilated in both transgenic and control mice. "Lipid vacuoles only.

in which the randomly inserted exogenous gene was present on both copies of the same chromosome. As reported previously (27), Southern blot assays with a mixture of two probes suggested that the copy number in the founder of line 7 and in the heterozygous progeny was about two. An independent assay was developed here using the PCR under conditions in which the same primers amplified a fragment of a different size from each gene. The results confirmed that the copy number was two in heterozygous transgenic mice from the line (Fig. 2). The copy number did not vary with propagation of the line through at least seven generations. The value for the ratio of the transgene to the endogenous gene as assayed by the PCR technique was $0.88 \pm 0.11 \mathrm{SD}$ in eight putative heterozygous mice randomly selected from generations II-VII (Fig. 1).

A few of the progeny from the brother-sister matings in generation III and IV (Fig. 1) were homozygotes as judged by an increase in copy number to about four (not shown). However, the mice with the higher copy number died within a few days of birth. Also, when viable progeny of the brother-sister matings in generations III and IV were mated to wild-type FVB/N mice, none gave litters in which all the mice were transgenic. Therefore, none of the viable progeny of the brother-sister matings was homozygous by this stringent genetic test.

Variable phenotype in the transgenic mice. Previous observations on line 7 suggested that expression of the transgene in the inbred strain FVB/N produced a variable phenotype in that about one-third of the heterozygous transgenic mice developed a lethal chondrodysplasia, whereas about two-thirds were viable (27). More extensive breeding of the mice within the
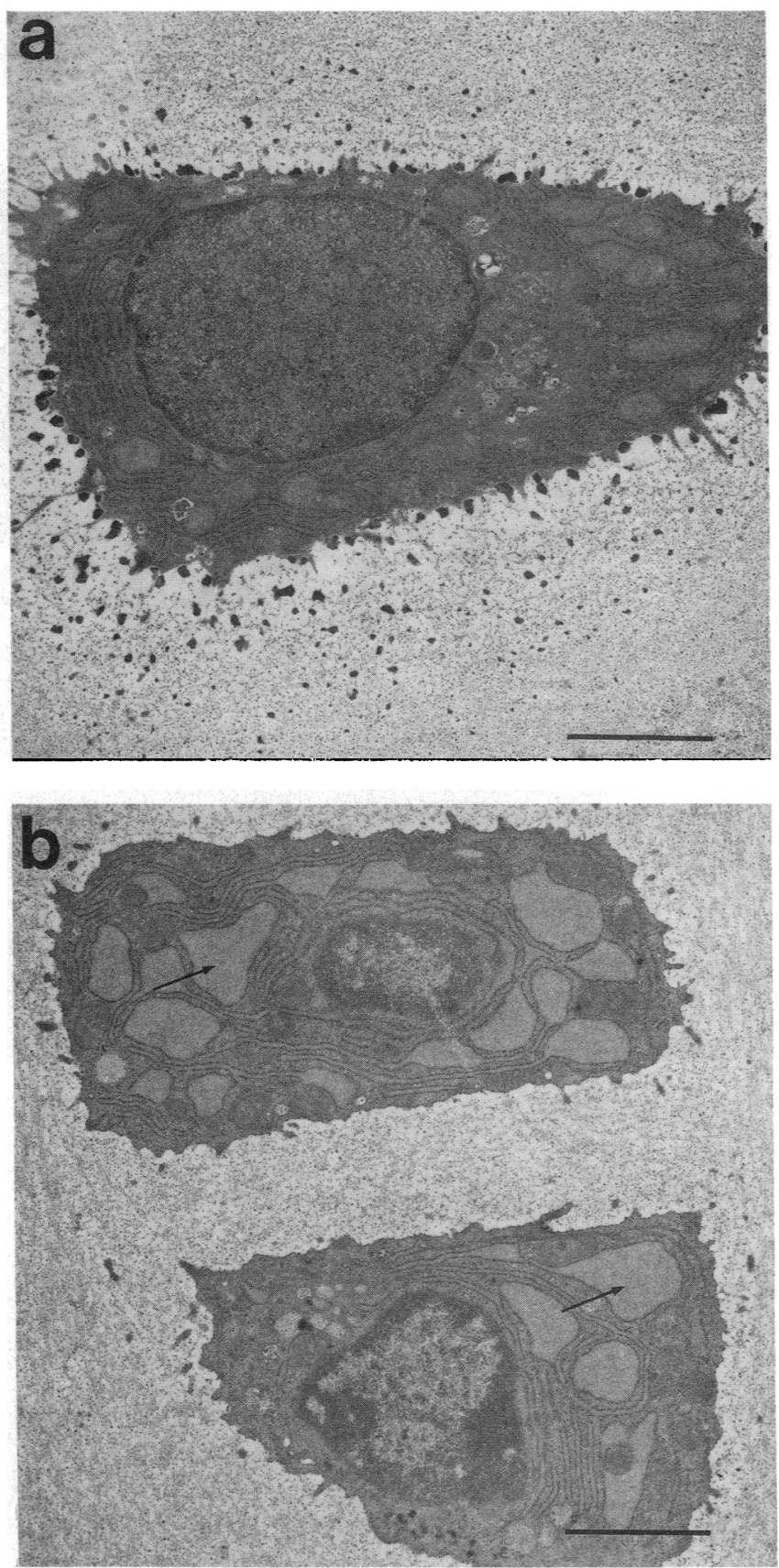

Figure 5. Electron micrographs of the chondrocytes from the growth cartilage of 3-month old control and heterozygous transgenic mice.

(a) In the control mice, the rough-surfaced endoplasmic reticulum is composed of a network of narrow cisternae seen regularly in normal secreting cells. $(b)$ In the heterozygous transgenic animals, the cisternae form large and dilated vacuoles containing proteinaceous material (arrows). Bar, $2 \mu \mathrm{m}$.

FVB/N strain (Fig. 1) further demonstrated the phenotypic variability. Of 283 transgenic pups generated by transgenic to FVB/N matings (Table I), 15\% of the transgenic mice had a cleft palate. Most of these mice were dead at birth and the

Figure 4. Electron micrographs of the extracellular matrix of the growth plate cartilage from 1-d-old mice. (a) Collagen fibrils in cartilage matrix from normal littermate are long and form a dense network. $(b)$ Collagen fibrils in cartilage matrix from heterozygous transgenic mouse are short and form a loose network. The dark dots are condensed proteoglycan molecules. Bar, $500 \mathrm{~nm}$. 

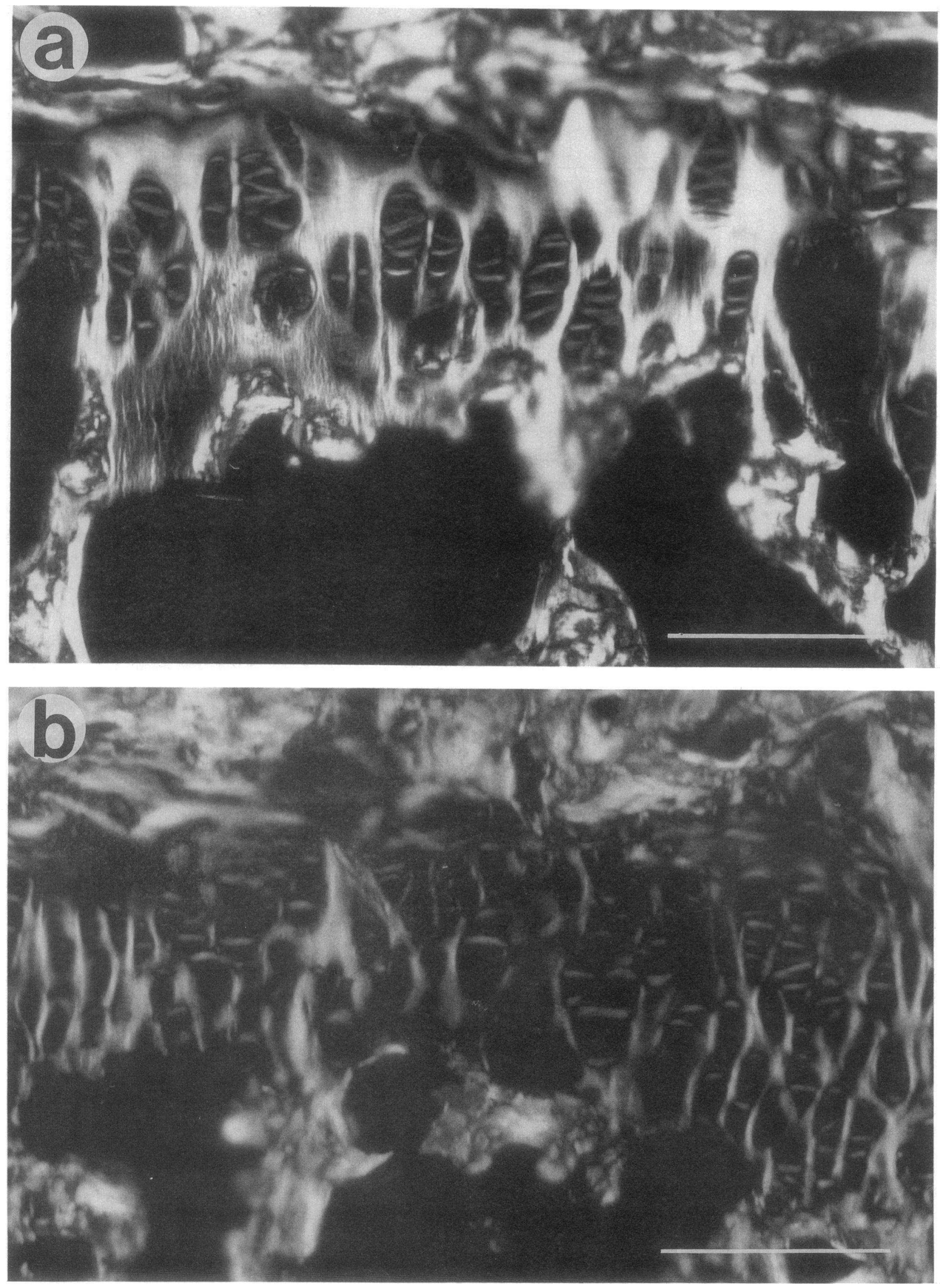

Figure 6. Polarized light micrograph of the picrosirius-stained growth plate cartilage from 3-mo-old mouse. (a) The birefringent, collagen-containing matrix cords are bright and thick in the control growth plate cartilage $(b)$ In the heterozygous transgenic cartilage matrix, the cords are darker and thinner indicating the presence of less and/or poorly organized collagen in these structures. Bar, $100 \mu \mathrm{m}$. 
remainder died within the next $24 \mathrm{~h}$. There was no marked gender preference in transmission of the phenotype in that the incidence of cleft palate and the lethal phenotype was the same when the line was propagated through male or the female transgenic mice. However, there was a small decrease in the male/ female ratio in the progeny of transgenic to transgenic matings (Table I).

Because viable homozygous mice were not obtained, all further studies were carried out on heterozygous mice generated from the transgenic mice designated as BM2 and BM3 in Fig. 1. The heterozygous transgenic mice with the lethal phenotype were distinguishable from control littermates because they weighed about $15 \%$ less $(1.18 \mathrm{~g} \pm 0.12 \mathrm{SD}$ vs. $1.36 \mathrm{~g} \pm 0.19 ; P$ value $<0.01$ ), and they had short and thick limbs, short snouts, cranial bulges, and delayed mineralization of bone ( see Figs. 3 and 4 in reference 27). The remaining $85 \%$ of transgenic mice did not have a cleft palate and were viable. A few of the viable mice could be distinguished from control littermates by smaller size, shorter limbs, and a cranial bulge. Many, however, were indistinguishable on the basis of physical appearance. At 1-d of age, the average weight of all the viable transgenic mice was not significantly different from normal littermates (1.30 $\mathrm{g} \pm 0.15 \mathrm{SD}$ vs. $1.36 \mathrm{~g} \pm 0.19 \mathrm{~g}$ for normal littermates). At 3-mo of age, the viable transgenic mice were again difficult to distinguish from normal littermates by gross features (not shown). However, they weighed $\sim 10 \%$ less than normal littermates (Fig. 3). At 12 and 15 mo, the male transgenic mice remained slightly smaller in weight, but the weight of the female transgenic mice approached the weight of normal littermates (Fig. 3). They were indistinguishable in appearance from normal littermates.

Femurs from the transgenic mice weighed less, were shorter, and had an increased ratio of width to length compared with that of normal littermates (Table II). The differences, however, were slightly less in the older mice. In 3-mo-old transgenic mice, the weights of the femurs were $14 \%$ less than controls $(P<0.001)$ and the lengths of the femurs were $11 \%$ less $(P$ $<0.001)$. In 15-mo-old transgenic mice the differences were $11 \%(P<0.01)$ and $8 \%(P<0.001)$, respectively. A similar trend was seen in the ratio of the width to the length of the femurs in that the $P$ value for the difference was $<0.001$ for 3-mo-old mice and $<0.01$ for 15 -mo-old mice.

Microscopy of cartilage matrix. As reported previously, microscopic examination of sections of nasal septum, spine, and elbow joint from 1-d-old mice from line 7 demonstrated a decrease in collagen fibrils in the cartilage matrix (27). Here the previous examinations were extended to compare cartilage from 1-d-, 3-mo-, and 15-mo-old transgenic mice.

In 1-d-old transgenic mice, collagen fibrils appeared less abundant, shorter, and more kinked in nasal septum, in the growth plate of tibiae and in condyles of the femur than in normal littermates (Fig. 4 and Table III). Also, the chondrocyte columns of the growth plate appeared less aligned. In addition, increased dilation of the cisternae of the rough endoplasmic reticulum was apparent in most chondrocytes.

In 3-mo-old mice, the same changes were present but less

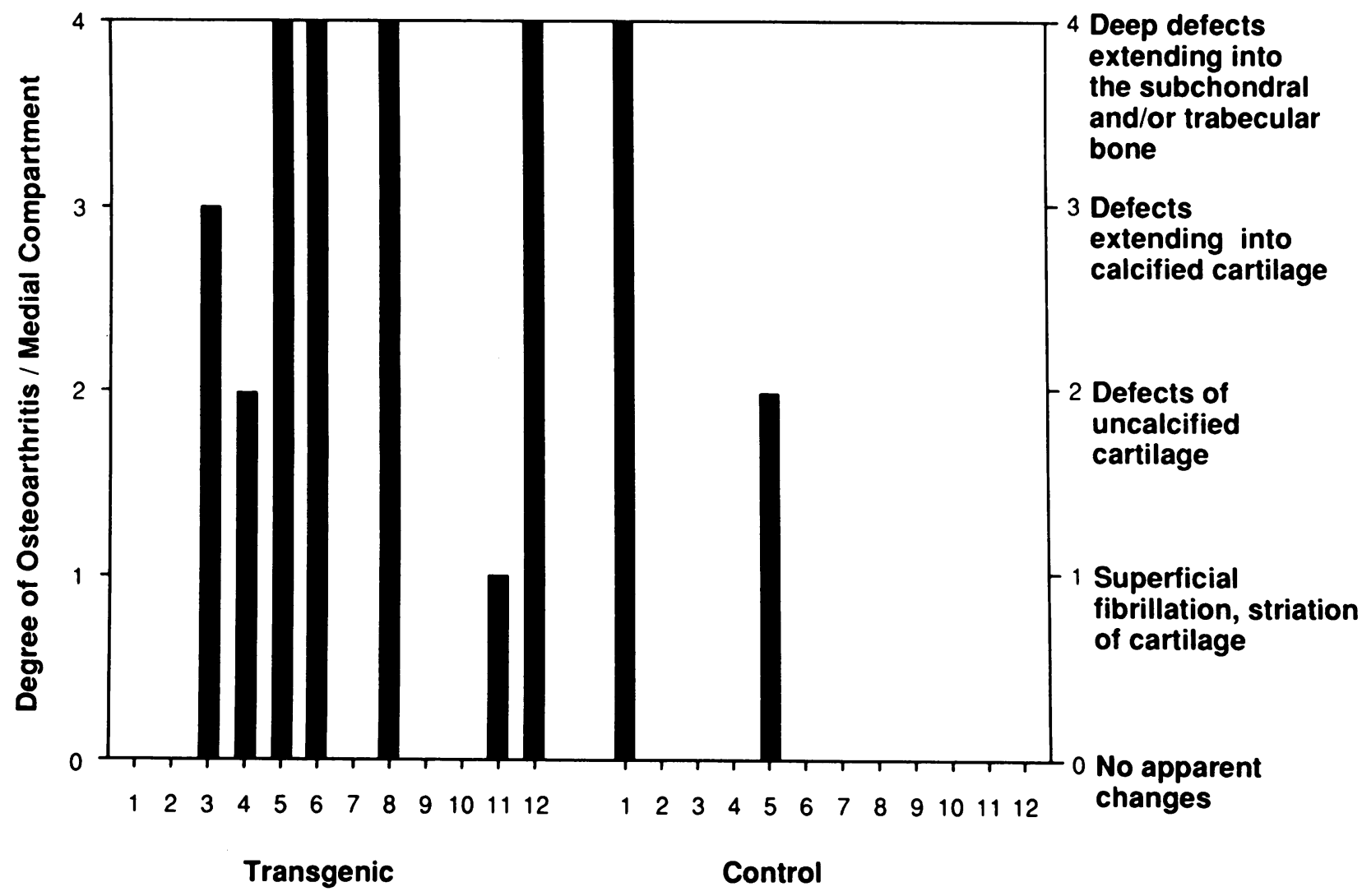

\section{Animal}

Figure 7. Graph showing the degree of microscopic degenerative changes in the medial compartment of the knee joint in heterozygous transgenic mice and normal littermates at $15 \mathrm{mo}$ of age. 
marked. There was dilation of the cisternae of the rough endoplasmic reticulum, particularly in chondrocytes in the growth plate (Fig. 5). The decrease in collagen fibrils in the cartilage matrix was no longer as apparent as in 1-d-old mice. In general, the differences were less apparent than in cartilage from the 1-d-old transgenic mice (Table III).

In the 15-mo-old mice, the differences from control littermates were still less apparent (Table III).

Measurements of polarized light retardation by cartilage matrix demonstrated a similar trend. In 1-d-old mice, differences were seen in the optical light path of polarized light in the cartilage matrix of the nasal septum and growth plate cartilage (Table IV). In 3-mo-old mice, similar differences were seen in the cartilage matrix of nasal septum, the growth plate, the deep zone of articular cartilage, and the superficial zone of articular cartilage (Fig. 6 and Table IV). In 15-mo-old mice, the differences were still present but less significant in three of the same tissues ( $P$ value of $<0.01$ instead of $<0.001$ ) and no difference was seen in the superficial zone of articular cartilage from regions of the tissue that appeared normal.

Microscopy of articular surfaces. Although the changes in cartilage matrix were less apparent in the older transgenic mice than in the younger transgenic mice, there were more marked changes in the articular surfaces of the knee, particularly in the medial compartment. 1 of 12 normal littermates had cartilage defects extending into the subchondral bone and another normal mouse had a defect confined to the uncalcified cartilage (Fig. 7). In contrast, 4 of 12 transgenic mice had defects extending to the subchondral bone and three other transgenic mice had superficial fibrillation with either striation of the cartilage, a lesion in the uncalcified cartilage, or a cartilage defect extending to the calcified articular cartilage. The osteoarthritic changes were apparent by light microscopy (Fig. 8) and by electron microscopy (Fig. 9). The differences between 15-mo-
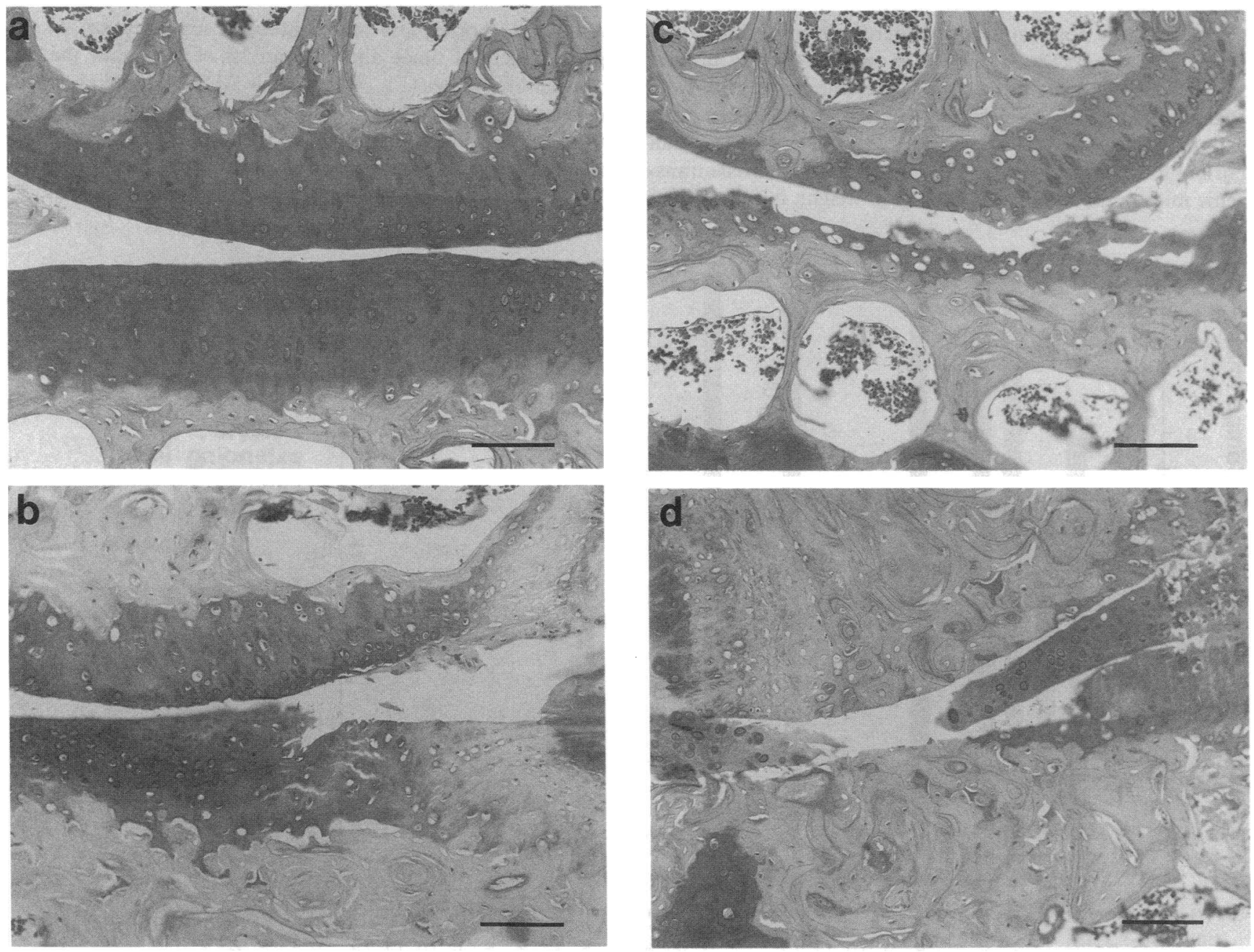

Figure 8. Light micrographs from the knee joints of 15-mo-old control and heterozygous transgenic mice demonstrating different degrees of degenerative changes. (a) Articular cartilage of femur and tibia from a control mouse (score 0 ). (b) The tibial articular cartilage (below) from a transgenic mouse shows an area with deep fibrillation (score 1). (c) The femoral cartilage (above) from a transgenic mouse shows both an uncalcified cartilage defect (score 2 ) and a defect extending into the calcified cartilage (score 3 ). The tibial cartilage (below) shows a defect extending into the calcified cartilage (score 3). $(d)$ Both the femoral and tibial condyles from a transgenic mouse demonstrate completely eroded articular cartilage and the lesions reach the subchondral bone (score 4). Note increase of subchondral bone. Bars, $100 \mu \mathrm{m}$. 
Table IV. Results of Optical Path Difference Measurements in Cartilage from Control and Transgenic Male Mice

\begin{tabular}{lccc}
\hline & \multicolumn{3}{c}{ Polarized light retardation* } \\
\cline { 2 - 4 } \multicolumn{1}{c}{ Tissue } & $\begin{array}{c}\text { 1-Day } \\
\text { mice }\end{array}$ & $\begin{array}{c}\text { 3-Month } \\
\text { mice }\end{array}$ & $\begin{array}{c}\text { 15-Month } \\
\text { mice }\end{array}$ \\
\hline Nasal septum & & $n m$ & \\
Control & & & \\
Transgenic & $16.9 \pm 2.1$ & $41.2 \pm 8.1$ & $9.7 \pm 2.6$ \\
Transgenic (cleft palate) & $7.7 \pm 1.5^{\S}$ & $15.2 \pm 6.0^{\S}$ & $5.9 \pm 3.0^{\ddagger}$ \\
Growth plate cartilage & $6.0 \pm 1.0^{\S}$ & & \\
Control & & & \\
Transgenic & $14.3 \pm 1.0$ & $43.6 \pm 5.6$ & $18.8 \pm 4.3$ \\
Articular cartilage deep & $6.6 \pm 1.2^{\ddagger}$ & $29.1 \pm 3.6^{\S}$ & $11.4 \pm 3.3^{\ddagger}$ \\
$\quad$ zone & & & \\
Control & & $53.0 \pm 7.3$ & $21.6 \pm 3.7$ \\
Transgenic & & $37.4 \pm 3.1^{\S}$ & $16.7 \pm 1.4^{\ddagger}$ \\
Articular cartilage superficial & & & \\
$\quad$ zone & & & \\
Control & & $44.3 \pm 3.7$ & $16.3 \pm 3.0$ \\
Transgenic & & $35.8 \pm 3.1^{\S}$ & $16.1 \pm 2.5^{\prime \prime}$ \\
Compact bone & & $70.5 \pm 8.9$ & \\
Control & & $70.2 \pm 7.5$ & \\
Transgenic & & & \\
\hline
\end{tabular}

* Mean \pm S.D.; at each time point number of animals investigated was 6-12. ${ }^{\ddagger} P<0.01$, significant; ${ }^{\S} P<0.001$, highly significant difference between the transgenic and control groups (Mann-Whitney's $U$ test). "Measured in regions of cartilage that appeared normal.

old normal littermates and transgenic mice (Fig. 7) was significant with a $P$ value of $<0.05$ as evaluated by the Kruskal-Wallis one-way Anova test.

In 3-mo-old transgenic mice, degenerative changes were seen in the lateral compartment of the knee instead of the medial compartment. Four of the transgenic mice, but only one of the normal littermates, demonstrated either a cleft within the articular cartilage or a loss of an uncalcified cartilage fragment (not shown).

Osteoarthritic changes demonstrable by $x$-ray. To examine further for osteoarthritic changes, $x$-ray films were prepared from knee joints from 12- and 15-mo-old heterozygous transgenic mice (Fig. 10), and they were evaluated by a clinical radiologist without access to the key (Table V). In 12-mo-old mice, osteoarthritic changes were seen in the knee joint of about twice as many of the transgenic mice as of normal littermates. Among the 15-mo-old mice, osteoarthritic changes were seen about three times more frequently among male transgenic mice than in normal male littermates. There was no apparent difference among the 15-mo-old females.

Spontaneous movements as an indication of joint degeneration. As a further indication of joint changes in the transgenic mice, the spontaneous movements of the mice were evaluated on two consecutive days. With 3-mo-old mice, there was no significant difference between transgenic mice and normal littermates (Table VI). With 15-mo-old mice, however, the number of spontaneous movements in the transgenic mice was less than in control littermates $(P<0.01)$.
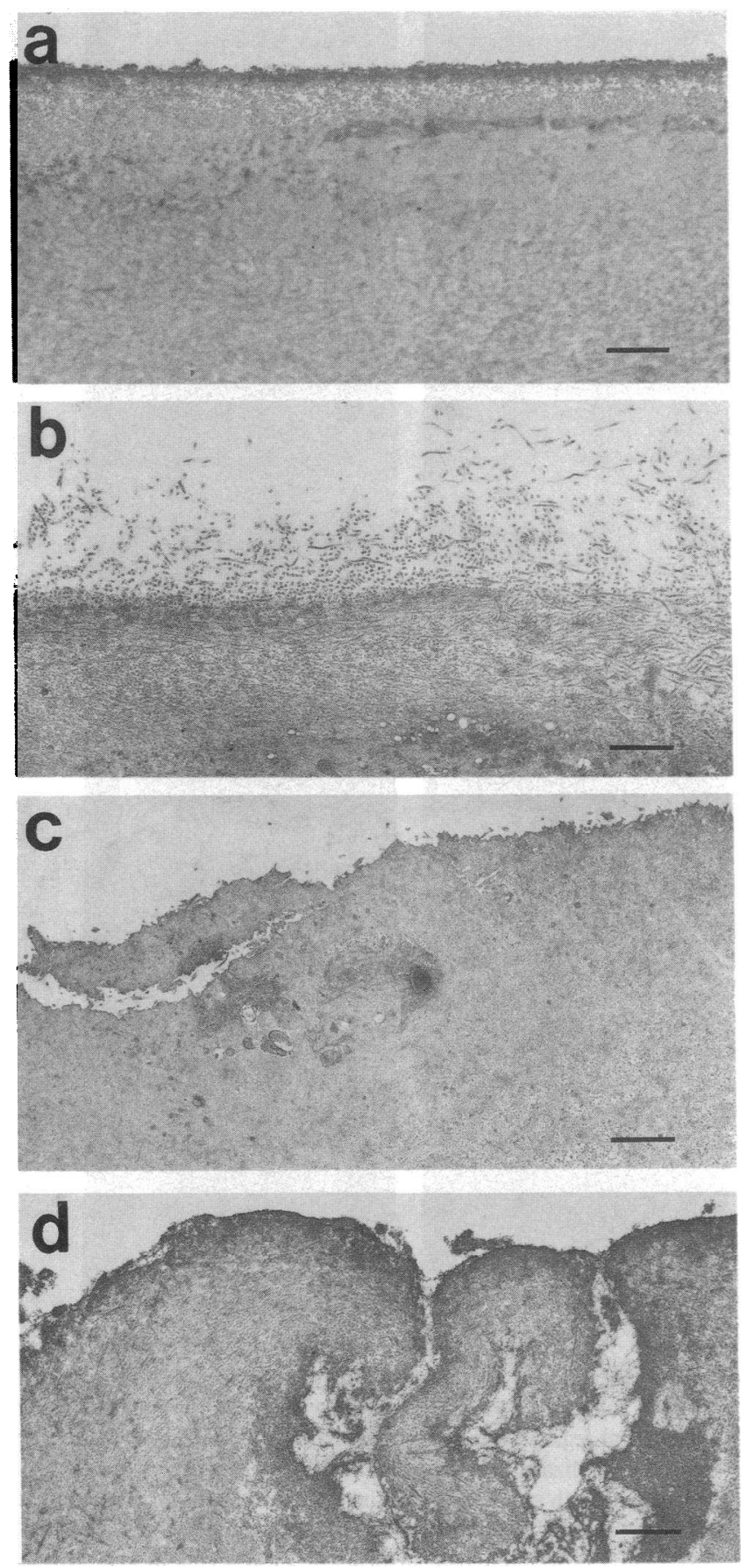

Figure 9. Low-power electron micrographs showing the femoral condylar articular cartilage surface of 15-mo-old control and heterozygous transgenic mouse. (a) Smooth cartilage surface from control mouse. $(b)$ Cartilage surface from a transgenic mouse demonstrating loose collagen fibrils above the surface of cartilage. (c) Uneven cartilage surface ("fibrillation") from a transgenic mouse with a fragment attached to the cartilage with only a narrow tissue bridge. $(d)$ Deep fibrillation or erosion of the cartilage surface from a transgenic mouse. Bars, $1 \mu \mathrm{m}$.

Chemical and biomechanical evaluation of femurs from the transgenic mice. Both the mineral content and collagen content of femoral bone were decreased in 3- and in 15-mo-old transgenic mice compared to control littermates ( Table VII). 

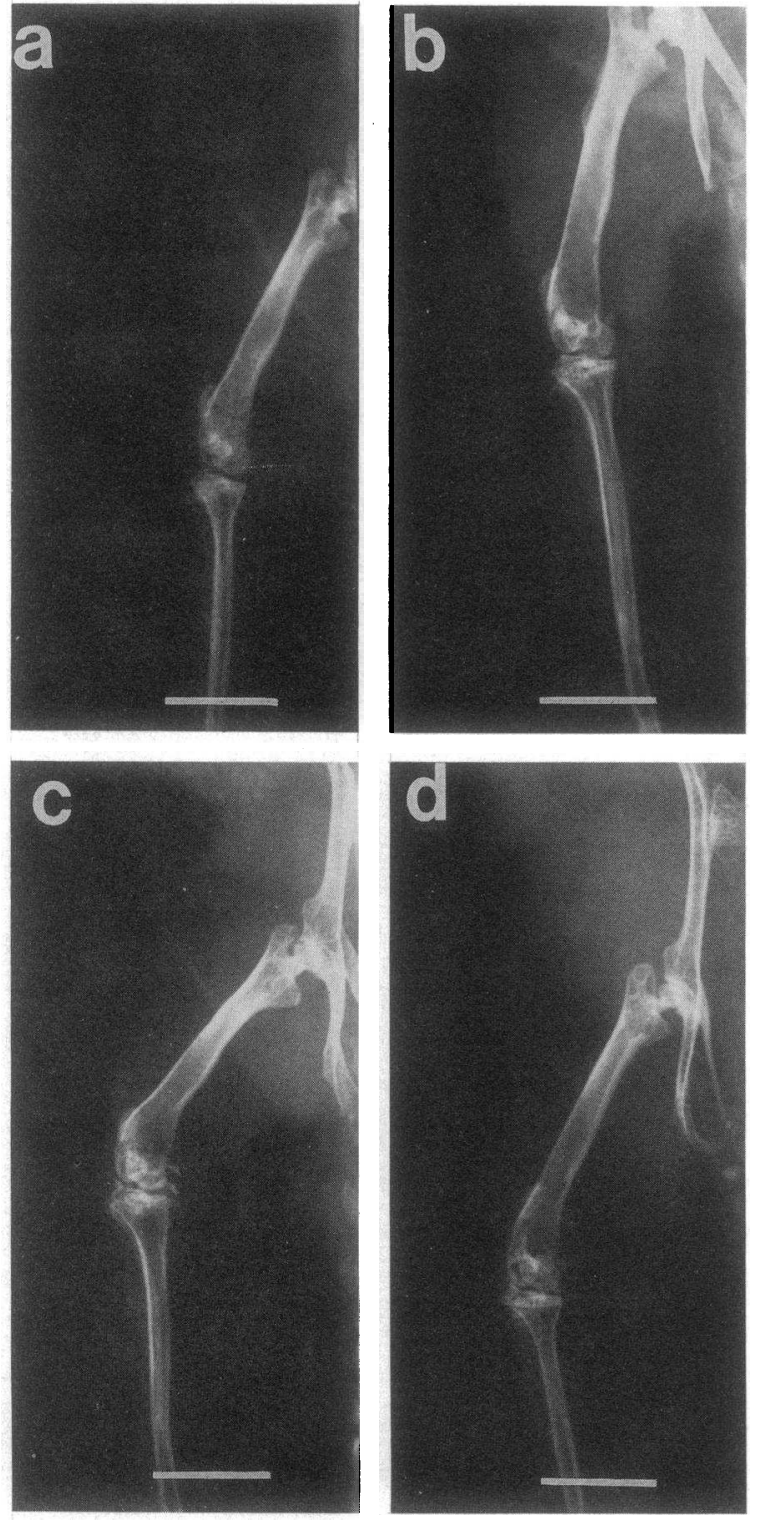

Figure 10. X-ray pictures from transgenic mouse knee joints showing degenerative changes. (a) Normal joint from control mouse with ossification centers within the menisci; two sesamoid bones located in the popliteal region on either side of the femur; and slight quadriceps tendon mineralization. Score $=0$. (b) Mild osteoarthritis in a transgenic mouse with calcification of the quadriceps tendon and collateral ligaments, especially laterally; and minimal subchondral sclerosis. Score $=1$. (c) Moderate osteoarthritis in a transgenic mouse with the development of bony spurs or osteophytes; thickening of the subchondral bone in medial or lateral tibial and femoral condyles; and appearance of subchondral cysts. Score $=2$. $(d)$ Severe osteoarthritis in a transgenic mouse with large marginal spurs; abundance of sclerotic subchondral bone in the condyles; and subchondral bone cysts. Score $=3$. Bars, $5 \mathrm{~mm}$.

In the 15-mo-old transgenic mice, however, the decrease in mineral was proportionately less than the decrease in collagen content. As a result, there was a marked increase in the ratio of mineral to collagen both in the intact femur and in the diaphysis $(P<0.001)$.

Biomechanical properties of bone of the transgenic mice. Measurements of the biomechanical properties of femoral
Table V. Osteoarthritic Changes Demonstrable by X-Ray in Control and Transgenic Mice

\begin{tabular}{lccccc}
\hline & \multicolumn{2}{c}{ Females } & & \multicolumn{2}{c}{ Males } \\
\cline { 2 - 3 } \cline { 5 - 6 } & Total & Abnormal* & & Total & Abnormal $^{*}$ \\
\hline $\begin{array}{l}12 \text {-mo-old } \\
\text { Control }\end{array}$ & 16 & 1 & & 15 & 1 \\
Transgenic & 17 & 2 & 17 & 3 \\
$\begin{array}{l}\text { 15-mo-old } \\
\text { Control }\end{array}$ & 12 & 1 & & 10 & 2 \\
Transgenic & 14 & 1 & 12 & 7 \\
\hline
\end{tabular}

* Score of 2 or 3 evaluated by $x$-ray as discussed in text. Mice were from multiple matings of progeny of mice designated as BM2 and BM3 (Fig. 1).

bone with a three-point bending test demonstrated that there was a decrease in the stiffness, in the force required to break the bone, and in the total energy for breakage (Table VIII). The largest difference observed was in the total energy for breakage in the 3-mo-old transgenic mice $(P<0.001)$, but there were no simple trends in comparison of the other values for 3- and 15-mo-old transgenic mice.

\section{Discussion}

The results here speak to two general issues. One is the marked variation in phenotypes previously observed in families with mutations in collagen genes. The other is the different roles of type II collagen in early development and in the mature organism.

The mutated COL2A1 gene used in the experiments described here was based on several mutations in the genes for type I procollagen that produced in-frame deletions of codons for the repeating -Gly-Xaa-Yaa- amino acid sequences of the collagen triple helix and cause lethal variants of OI (20-22). Because the collagen triple helix is formed by a series of hydrogen bonds and water bridges that link-Gly-Xaa-Yaa-sequences

Table VI. Spontaneous Movements in Control and Transgenic Mice

\begin{tabular}{cc}
\hline & $\begin{array}{c}\text { Movements per } \\
\text { mouse/30 } \text { min }^{*}\end{array}$ \\
\hline 3-mo-old & $21,501 \pm 1,302$ \\
Control & $(n=31)$ \\
Transgenic & $20,022 \pm 1,663$ \\
& $(n=28)$ \\
15-mo-old & $7,218 \pm 1,212$ \\
Control & $(n=28)$ \\
& $3,432 \pm 658^{\ddagger}$ \\
Transgenic & $(n=22)$ \\
& \\
\hline
\end{tabular}

\footnotetext{
* Mean \pm SE; $n=$ number of female and male mice. Movements were recorded twice on consecutive days. ${ }^{\ddagger} P<0.01$, significant difference between transgenic and control groups (Mann-Whitney's U-test).
} 
Table VII. Mineral and Collagen Contents of Femoral Bone from 3- and 15-mo-old Female Transgenic Mice*

\begin{tabular}{|c|c|c|c|c|c|c|}
\hline & \multicolumn{2}{|c|}{ Mineral } & \multicolumn{2}{|c|}{ Collagen } & \multicolumn{2}{|c|}{ Mineral/Collagen } \\
\hline & 3-mo & 15-mo & 3-mo & 15-mo & 3-mo & 15-mo \\
\hline & & & & & & \\
\hline \multicolumn{7}{|l|}{ Whole femur } \\
\hline Control & $21.9 \pm 1.5$ & $27.1 \pm 3.6$ & $4.1 \pm 0.9$ & $4.2 \pm 0.8$ & $5.8 \pm 1.7$ & $6.6 \pm 1.2$ \\
\hline Transgenic & $18.8 \pm 0.8^{11}$ & $24.0 \pm 3.0^{\ddagger}$ & $3.5 \pm 1.0$ & $2.8 \pm 0.5^{\prime \prime}$ & $5.8 \pm 1.6$ & $8.6 \pm 1.4^{\| \prime}$ \\
\hline \multicolumn{7}{|l|}{ Epiphysis } \\
\hline Control & $7.4 \pm 0.8$ & $8.7 \pm 1.6$ & $2.0 \pm 0.2$ & $1.6 \pm 0.5$ & $3.5 \pm 0.2$ & $5.9 \pm 1.6$ \\
\hline Transgenic & $7.1 \pm 0.8$ & $8.5 \pm 1.6$ & $2.4 \pm 0.8$ & $1.2 \pm 0.4^{\ddagger}$ & $3.4 \pm 1.1$ & $7.4 \pm 2.2^{\ddagger}$ \\
\hline \multicolumn{7}{|l|}{ Diaphysis } \\
\hline Control & $14.4 \pm 1.3$ & $18.0 \pm 1.8$ & $2.4 \pm 0.5$ & $2.5 \pm 0.5$ & $5.9 \pm 0.9$ & $7.0 \pm 1.3$ \\
\hline Transgenic & $11.8 \pm 1.0^{8}$ & $15.3 \pm 2.1^{\S}$ & $1.8 \pm 0.3^{\S}$ & $1.6 \pm 0.4^{\prime \prime}$ & $6.8 \pm 1.5$ & $10.1 \pm 2.9^{\| 1}$ \\
\hline
\end{tabular}

* All values are from 14-17 mice except that only four to seven samples of epiphyses and diaphyses from 3-mo-old mice were assayed for mineral and collagen content. ${ }^{\ddagger} P<0.05$, almost significant; $\$ P<0.01$, significant; $" P<0.001$, highly significant difference between the transgenic and control groups (Student's $t$-test and Mann-Whitney's U test).

in one pro $\alpha$ chain to equivalent -Gly-Xaa-Yaa- sequences in the two other pro $\alpha$ chains, the presence of one shortened pro $\alpha$ chain in a procollagen molecule can prevent folding into a stable triple helix and degradation of all three pro $\alpha$ chains. In effect, therefore, the mutated gene was designed to produce depletion of type II procollagen and type II collagen in the transgenic mice by a transdominant effect of the mutated gene at the protein level. Previous studies with chondrocytes from transgenic mice expressing the mutated gene demonstrated that the shortened pro $\alpha 1$ (II) synthesized from the gene formed intracellular hybrid molecules with normal pro $\alpha 1$ (II) chains synthesized from the endogenous mouse genes (27). Microscopy of cartilage from the transgenic mice demonstrated that there was dilation of the cisternae of the rough endoplasmic reticulum much as seen in fibroblasts in patients in which mutations in pro $\alpha 1(\mathrm{I})$ or pro $\alpha 2(\mathrm{I})$ chains of type I procollagen interfere with folding of the molecule into a triple-helical conformation and cause an increase in the steady-state level of intracellular pro $\alpha$ chains $(20,21)$. Also, there was an apparent decrease in the amount of collagen fibrils in cartilage matrix.

The phenotype seen in the most severely affected transgenic mice was dwarfism, a short snout, delayed mineralization and a cleft palate. Similar but not identical phenotypes were seen in the transgenic mice that were prepared by Garofalo et al. (28) that expressed a COL2A1 gene with a mutation of a glycine codon to a cysteine codon, and the transgenic mice that were prepared by Metsäranta et al. (29) that expressed a COL2A1 gene with a deletion of 15 codons from the triple-helical domain.

Comparisons of young with 12- and 15-mo-old mice demonstrated that even among the mice with the mild phenotype there was decreasing evidence of a chondrodysplasia as the mice grew older. The older mice were still significantly different from controls in length, weight, mineral content, and collagen content of femurs. The most striking finding in the 15-moold transgenic mice, however, was the marked erosion of articular surfaces that was found in only a few normal littermates. The microscopic changes in articular surfaces were in part reflected by $x$-ray evidence of degenerative changes in the knee and by a decrease in spontaneous movements in the mice. Therefore, a major manifestation of expression of transgene in the older mice was degenerative changes of articular cartilage

Table VIII. Biomechanical Properties of Femoral Bone from 3- and 15-mo-old Female Transgenic Mice*

\begin{tabular}{|c|c|c|c|c|c|c|}
\hline & \multicolumn{2}{|c|}{ Stiffness } & \multicolumn{2}{|c|}{ Force } & \multicolumn{2}{|c|}{ Energy } \\
\hline & 3-mo & 15-mo & 3-mo & 15-mo & 3-mo & $15-\mathrm{mo}$ \\
\hline & \multicolumn{2}{|c|}{$\times 10^{3} \mathrm{Nt} / \mathrm{m}$} & \multicolumn{2}{|c|}{$N t$} & \multicolumn{2}{|c|}{$\times 10^{-3} \mathrm{Ntm}$} \\
\hline \multicolumn{7}{|l|}{ Diaphysis } \\
\hline Control & $71.7 \pm 9.3$ & $97.3 \pm 33.0$ & $16.6 \pm 1.4$ & $26.5 \pm 4.0$ & $8.9 \pm 1.9$ & $8.5 \pm 2.5$ \\
\hline Transgenic & $67.3 \pm 20.3$ & $73.1 \pm 21.5^{\ddagger}$ & $15.5 \pm 1.7^{\ddagger}$ & $21.0 \pm 6.7^{\S}$ & $6.4 \pm 0.8^{\prime \prime}$ & $5.7 \pm 2.4^{\S}$ \\
\hline \multicolumn{7}{|l|}{ Epiphysis } \\
\hline Control & $229 \pm 32$ & $340 \pm 79$ & $54.9 \pm 13.6$ & $67.5 \pm 12.2$ & $8.4 \pm 3.1$ & $8.2 \pm 2.2$ \\
\hline Transgenic & $162 \pm 20^{\prime \prime}$ & $347 \pm 93$ & $37.0 \pm 6.2^{\ddagger}$ & $59.1 \pm 12.9$ & $6.2 \pm 2.0$ & $7.2 \pm 1.8$ \\
\hline
\end{tabular}

* Mean \pm SD for 14-17 mice except that only six or seven 3-mo-old mice were used for assays of epiphyses. ${ }^{\ddagger} P<0.05$, almost significant; ${ }^{8} P$ $<0.01$, significant; " $P<0.001$, highly significant difference between the transgenic and control groups (Student's $t$-test and Mann-Whitney's U test). 
similar to osteoarthritis. The results suggest that the expression of the mutated gene in part made it possible to distinguish the two apparent functions of hyaline cartilage, one to serve as a temporary template for the development of skeletal structures and the other to provide the organism with permanent skeletal components that are flexible but resilient to compression. In addition, the results support the hypothesis that there may be phenotypic overlap between relatively rare diseases of connective tissue such as chondrodysplasias and some subsets of more common disorders such as primary generalized osteoarthritis (36).

Chemical assay on femoral bone demonstrated a decrease in both the mineral content and total collagen content, observations that are consistent with many previous observations suggesting a critical role for type II collagen in endochondral ossification. Surprisingly, however, there was an increase in the ratio of mineral to collagen. The increase was seen in 15-moold mice and not in 3-mo-old mice, and it may well reflect a compensatory mechanism to increase the strength of bone.

One striking observation here was the marked differences in phenotype observed with propagation of the mutated gene in an inbred strain of mice. Examination of 283 transgenic mice demonstrated that $\sim 15 \%$ had a cleft palate whereas the remainder did not. Moreover, the mice with a cleft palate died on the day of birth or shortly thereafter, apparently because they were unable to nurse. Many of the remaining viable $85 \%$ of transgenic mice were not distinguishable from normal littermates on the basis of appearance, and at day 1 they did not on average weigh significantly less than control littermates. Microscopy of cartilage from the 1-d-old viable transgenic mice revealed changes similar to those seen in nonviable mice, but it was apparent that the phenotype varied from a lethal chondrodysplasia to a very mild disorder. There was no correlation between phenotype and sex of the parents or progeny, and the same variation was seen with multiple matings within the same inbred line. Therefore, it is difficult to ascribe the phenotypic variation to differences in the genetic background of the mice (37). Instead, it is more likely explained by variations in uterine environment or stochastic events during development. We have recently observed similar variations in a phenotype of fragile bones in an inbred line of transgenic mice expressing an internally deleted COL1A1 gene (38).

\section{Acknowledgments}

The work was supported in part by grants from the Lucille P. Markey Charitable Trust and the March of Dimes/Birth Defects Foundation and grant AR-39740 from the National Institutes of Health.

\section{References}

1. Kühn, K. 1987. The classical collagens: types I, II and III. In Structure and Function of Collagen Types. R. Mayne and R. E. Burgeson, editors. Academic Press, Inc., Orlando, FL. 1-42.

2. Hunziker, E. B., and W. Herrmann. 1990. Ultrastructure of cartilage. In Ultrastructure of Skeletal Tissues. E. Bonucci and P. Motta, editors. Kluwer Academic Publishers, Norwall, MA. 79-109.

3. Thorogood, P., J. Bee, and K. von der Mark. 1986. Transient expression of collagen type II at epitheliomesenchymal interfaces during morphogenesis of the cartilaginous neurocranium. Dev. Biol. 116:497-509.

4. Cheah, K. S. E., E. T. Lau, P. K. Au, and P. P. L. Tam. 1991. Expression of the mouse $\alpha 1$ (II) collagen gene is not restricted to cartilage during development. Development (Camb.). 111:945-953.
5. Wood, A., D. E. Ashhurst, A. Corbett, and P. Thorogood. 1991. The transient expression of type II collagen at tissue interfaces during mammalian craniofacial development. Development (Camb.). 111:955-968.

6. Rimoin, D. L., and R. S. Lachman. 1990. The chondrodysplasias. In Principles and Practice of Medical Genetics, Volume 2, Section H. 2nd edition. A. E. H. Emery and D. L. Rimoin, editors. Churchill Livingston, Edinburgh. 895-932.

7. Francomano, C. A., R. M. Liberfarb, T. Hirose, I. H. Maumenee, E. A. Streeten, D. A. Meyers, and R. E. Pyeritz. 1987. The Stickler syndrome: evidence for close linkage to the structural gene for type II collagen. Genomics. 1:293-296.

8. Knowlton, R. G., P. L. Katzenstein, R. W. Mowkowitz, E. J. Weaver, C. J. Malemud, M. N. Pathria, S. A. Jimenez, and D. J. Prockop. 1990. Genetic linkage of a polymorphism in the type II procollagen gene (COL2A1) to primary osteoarthritis associated with mild chondrodysplasia. N. Engl. J. Med. 322:526530.

9. Fryer, A. E., M. Upadhyaya, M. Litlter, P. Bacon, D. Watkins, P. Tsipouras, and P. S. Harper. 1990. Exclusion of COL2A1 as a candidate gene in a family with Wagner-Stickler syndrome. J. Med. Genet. 27:91-93.

10. Ahmad, N. N., L. Ala-Kokko, R. G. Knowlton, S. A. Jimenez, E. J. Weaver, J. I. Maguire, W. Tasman, and D. J. Prockop. 1991. Stop codon in the procollagen II gene (COL2A1) in a family with the Stickler syndrome (arthroopthalmopathy). Proc. Natl. Acad. Sci. USA. 88:6624-6627.

11. Ahmad, N. N., D. M. McDonald-McGinn, E. H. Zackai, R. G. Knowlton, D. LaRossa, J. DiMascio, and D. J. Prockop. 1993. A second mutation in the type II procollagen gene (COL2A1) causing Stickler syndrome (arthro-ophthalmopathy) is also a premature termination codon. Am. J. Hum. Genet. 52:39-45.

12. Brown, D. M., B. E. Nichols, T. A. Weingeist, A. E. Kimura, V. C. Sheffield, and E. M. Stone. 1992. Procollagen II gene mutation in Stickler syndrome. Arch. Ophthalmol. 110:1589-1593.

13. Ritvaniemi, P., J. Hyland, J. Ignatius, K. I. Kivirikko, D. J. Prockop, and L. Ala-Kokko. 1993. A fourth example suggests premature termination codons in the COL2A1 gene are a common cause of the Stickler syndrome: analysis of the COL2Al gene by denaturing gradient gel electrophoresis. Genomics. In press.

14. Vissing, H., M. D'Alessio, B. Lee, F. Ramirez, M. Godfrey, and D. W. Hollister. 1989. Glycine to serine substitution in the triple helical domain of pro $\alpha 1$ (II) collagen results in a lethal perinatal form of short-limbed dwarfism. $J$. Biol. Chem. 264:18265-19267.

15. Lee, B., H. Vissing, F. Ramirez, D. Rogers, and D. Rimoin. 1989. Identifcation of the molecular defect in a family with spondyloepiphyseal dysplasia. Science (Wash. DC). 244:978-980.

16. Tiller, G. E., D. L. Rimoin, L. W. Murray, and D. H. Cohn. 1990. Tandem duplication within a type II collagen gene (COL2A1) exon in an individual with spondyloepiphyseal dysplasia. Proc. Natl. Acad. Sci. USA. 87:3889-3893.

17. Chan, D., and W. G. Cole. 1992. Low basal transcription of genes for tissue-specific collagens by fibroblast and lymphoblastoid cells: application to the characterization of a glycine 997 to serine substitution in $\alpha 1$ (II) collagen chains of a patient with spondyloepiphyseal dysplasia. J. Biol. Chem. 226:12487-12494.

18. Palotie, A., P. Văisänen, J. Ott, L. Ryhänen, K. Elima, M. Vikkula, K. Cheah, E. Vuorio, and L. Peltonen. 1989. Predisposition to familial osteoarthrosis linked to type II collagen gene. Lancet. $i: 924-927$.

19. Ala-Kokko, L., C. T. Baldwin, R. W. Moskowitz, and D. J. Prockop. 1990. Single base mutation in the type II procollagen gene (COL2A1) as a cause of primary osteoarthritis associated with a mild chondrodysplasia. Proc. Natl. Acad. Sci. USA. 87:6565-6568.

20. Byers, P. H., and R. D. Steiner. 1992. Osteogenesis imperfecta. Annu. Rev. Med. 43:269-282.

21. Kuivaniemi, H., G. Tromp, and D. J. Prockop. 1991. Perspectives: genetic causes of aortic aneurysms. J. Clin. Invest. 88:1441-1444.

22. Prockop, D. J. 1990. Mutations that alter the primary structure of type I collagen: the perils of a system for generating large structures by the principle of nucleated growth. J. Biol. Chem. 265:15349-15352.

23. Stacey, A., J. Bateman, T. Choi, T. Mascara, W. Cole, and R. Jaenisch. 1988. Perinatal lethal osteogenesis imperfecta in transgenic mice bearing an engineered mutant pro- $\alpha 1$ (I) collagen gene. Nature (Lond.). 332:131-136.

24. Bonadio, J., T. L. Saunders, E. Tsai, S. A. Goldstein, J. Morris-Winman, L. Brinkley, D. F. Dolan, R. A. Altschuler, J. E. Hawkins, Jr., J. F. Bateman, et al. 1990. Transgenic mouse model of the mild dominant form of osteogenesis imperfecta. Proc. Natl. Acad. Sci. USA. 87:7145-7649.

25. Khillan, J. S., A. S. Olsen, S. Kontusaari, B. Sokolov, and D. J. Prockop. 1991. Transgenic mice that express a mini-gene version of the human gene for type I procollagen (COL1A1) develop a phenotype resembling a lethal form of osteogenesis imperfecta. J. Biol. Chem. 266:23373-23379.

26. Prockop, D. J., and K. I. Kivirikko. 1984. Heritable diseases of collagen. N. Engl. J. Med. 311:376-386.

27. Vandenberg, P., J. S. Khillan, D. J. Prockop, H. Helminen, S. Kontusaari, and L. Ala-Kokko. 1991. Expression of a partially deleted gene of human type II procollagen (COL2A1) in transgenic mice produces a chondrodysplasia. Proc. Natl. Acad. Sci. USA. 88:7640-7644.

28. Garofalo, S., E. Vuorio, M. Metsäranta, R. Rosati, D. Toman, J. Vaughan, G. Lozano, R. Mayne, J. Ellard, W. Horton, et al. 1991. Reduced 
amounts of cartilage collagen fibrils and growth plate anomalies in transgenic mice harboring a glycine-to-cysteine mutation in the mouse type II procollagen $\alpha 1$-chain gene. Proc. Natl. Acad. Sci. USA. 88:9648-9652.

29. Metsäranta, M., S. Garofalo, G. Decker, M. Rintala, B. de Crombrugghe, and $\mathrm{E}$. Vuorio. 1992. Chondrodysplasia in transgenic mice harboring a 15-amino acid deletion in the triple helical domain of pro $\alpha 1$ (II) collagen chain. J. Cell Biol. 118:203-212.

30. Nakata, K., K. Yamamura, J. Miyazaki, B. R. Olsen, Y. Muragaki, Y. Yamada, and T. Kimura. 1992. Articular cartilage disorders in transgenic mice harboring minigene of cartilage specific type IX collagen. Trans. 38th Annu. Meet. Orthopaed. Res. Soc. 17(Sect. 1):251.

31. Sangiorgi, F. O., V. Benson-Chanda, W. J. de Wet, M. E. Sobel, P. Tsipouras, and F. Ramirez. 1985. Isolation and partial characterization of the entire human proa 1 (II) collagen. Nucleic Acids Res. 13:2207-2225.

32. Wilhelmi, G., and R. Faust. 1976. Suitability of the C57 Black mouse as an experimental animal for the study of skeletal changes due to aging, with special reference to osteo-arthrosis and its response to tribenoside. Pharmacology. 14:289-296.
33. Inoye, M. 1976. Differential staining of cartilage and bone in fetal mouse skeleton by alcian blue and alizarin red S. Congenital Anomalies 16:171-173.

34. Woessner, J. R. 1961. The determination of hydroxyproline in tissue and protein samples containing small proportions of this imino acid. Arch. Biochem. Biophys. 93:440-447.

35. Kiebzak, G. M., R. Smith, C. C. Gundberg, J. C. Howe, and B. Sacktor. 1988. Bone status of senescent male rats: chemical, morphometric and mechanical analysis. J. Bone Miner. Res. 3:37-44.

36. Prockop, D. J. 1992. Mutations in collagen genes as a cause of connectivetissue diseases. N. Engl. J. Med. 326:540-546.

37. Hogan, B., F. Constantini, and E. Lacy. 1986. Developmental genetics and embryology of the mouse: past, present and future. In Manipulating the Mouse Embryo. A Laboratory Manual. Cold Spring Harbor Laboratory, Cold Spring Harbor, NY. 1-16.

38. Pereira, R. P., J. S. Khillan, H. J. Helminen, E. L. Hume, and D. J. Prockop. 1993. Transgenic mice expressing a partially deleted gene for type I procollagen (COL1Al): a breeding line with a phenotype of spontaneous fractures and decreased bone collagen and mineral. J. Clin. Invest. 91:709-716. 